\title{
Sosialisasi Empat Pilar Kebangsaan Pengurus Partai di Kota Serang Provinsi Banten
}

\author{
Furtasan Ali Yusuf*1, Bambang Dwi Suseno ${ }^{2}$ Basrowi $^{3}$ \\ 1,2,Program Pascasarjana Magister Manajemen Universitas Bina Bangsa \\ ${ }^{3}$ Staf Ahli Rektor, Universitas Bina Bangsa \\ *e-mail: fay@binabangsa.ac.id ${ }^{1}$ bambangds_mm@binabangsa.ac.id, basrowi@binabangsa.ac.id
}

\begin{abstract}
This community service aims to socialize the four pillars of nationality which include Pancasila, the 1945 Constitution, the Republic of Indonesia, and Bhinneka Tunggal lka. The methods used are lectures, questions and answers, and webinars. The community service was carried out in November 2020 at the Regional Leadership Council (DPD) Office, Nasdem Party, in Pakupatan Serang, Banten. Based on the results of the analysis, it is known that, there is an increase in the understanding of the four pillars of nationality, which means between before and after socialization. The increase that occurred was $35 \%$ from an average value of $42 \%$ to an average of $77 \%$. Through this service activity, follow-up can be carried out, so that the four pillars of nationality can be carried out well.
\end{abstract}

Keywords: Pancasila, UUD 1945, NKRI, Bhinneka Tunggal lka.

\begin{abstract}
Abstrak
Pengabdian kepada masyarakat ini bertujuan untuk mensosialisasikan empat pilar kebangsaan yang meliputi Pancasila, undang-undang Dasar 1945, NKRI, dan Bhinneka Tunggal Ika. Metode yang digunakan yaitu ceramah, tanya jawab, dan webinar. Pengabian kepada masyarakat dilaksanakan pada bulan November 2020 bertempat di Kantor DPD Partan Nasdem Pakupatan Serang Banten. Berdasarkan hasil analisis diketahui bahwa, terdapat peningkatan pemahaman empat pilar kebangsaan yang berarti antara sebelum dan sesudah sosialisasi. Peningkatan yang terjadi sebesar $35 \%$ dari rata-rata nilai $42 \%$ menjadi rata-rata $77 \%$. Melalui kegiatan pengabdian ini, dapat dilakukan tindak lanjut, sehingga empat pilar kebangsaan tersebut dapat terlaksana dengan baik.
\end{abstract}

Kata kunci:: Pancasila, UUD 1945, NKRI, Bhinneka Tunggal lka.

\section{PENDAHULUAN}

Empat pilar kebangsaan yang meliputi Pancasila, undang-undang Dasar 1945, NKRI, dan Bhinneka Tunggal lka sangat urjen untuk dilakukan, karena bangsa Indonesia akan menjadi bangsa yang kuat manakala keempat pilar kebangsaan itu dapat tertanamkan kepada seluruh masyarakat Indonesia.

Empat pilar kebangsaan merupakan "Soko Guru" negara Republik Indonesia. Ketika keempat soko guru tersebut tidak berdiri kokoh maka eksistensi negara Indonesia akan sangat terganggu. Dengan empat pilar kebangsaan yang kokoh maka mampu memberikan perlindungan kepada seluruh masyarakat Indonesia dari berbagai ancaman, gangguan, dan ketertiban baik dari dalam maupun luar negera Indonesia.

Menurut BPIP (2020) empat pilar kebangsaan menjadi pilar penting yang akan memberikan perlindungan bagi segenap bangsa Indonesia dalam mewujudkan kesejahteraan seluruh rakyat Indonesia. Tanpa empat pilar tersebut, kejayaan dan kelangsungan hidup bangsa Indonesia akan terancam. 
Kemeninfokom (2020) menjelaskan bahwa Pancasila sebagai Ideologi suatu negara sekaligus sebagai dasar hukum di Indonesia. Oleh karena itu, Seluruh peraturan perundangan tidak boleh bertentangan dengan Pancasila.

Kemenkumham. (2020) menjelaskan bahwa, UUD 45 merupakan pengejawantahan nilai-nilai Pancasila, karena di dalam Pembukaan dan batang tubuhnya, seluruhnya mencerminkan nilai-nilai Pancasila.

NKRI sebagai sebuah harga mati bagi Bangsa Indonesia. Tidak ada Gerakan separatis yang mampu memecah belah bangsa Indonesia. Gerakan yang berusaha memecah bangsa Indonesia akan berhadapan dengan seluruh rakyat Indonesia.

Bhinneka tunggal ika sebagai perwujukan aneka ragam budaya, suku, ras, agama yang ada di Indonesia. Seluruh perbedaan tersebut bukan merupakan bibit perpecahan, akan tetapi menjadi unsur pemersatu keutuhan bangsa Indonesia.

Mengingat pentingnya empat pilar tersebut, sudah selayaknya manakala empat pilar kebangsaan tersebut terus untuk digalakkan sehingga seluruh rakyat Indonesia mampu menghayati dan mengamalkannya dalam kehidupan berbangsa dan bernengara.

\section{METODE}

. Metode yang digunakan yaitu ceramah, tanya jawab, dan webinar. Pengabian kepada masyarakat dilaksanakan pada bulan November 2020 bertempat di Kantor DPD Partan Nasdem Pakupatan Serang Banten. Pelaksanaan pengabdian dibagi dalam empat sesi. Sesi pertama yaitu, Pancasila. Metode yang digunakan adalah ceramah, tanya jawab dan menyelesaikan soal. Sesi kedua yaitu Undangundang dasar 1945. Metode yang digunakan yaitu diskusi, tanya jawab, dan menyelesaikan kasus. Sesi ketiga yaitu Bhinneka tunggal ika. Metode yang digunakan yaitu seperti pada metode materi kedua, yaitu diskusi, tanya jawab. Sesi keempat, yaitu NKRI. Metode yang digunakan adalah studi kasus.

Proses pengumpulan data dilakukan dua tahap yaitu pre test dan post test. Pre test digunakan untuk mengukur kompetensi awal yang sudah dimiliki oleh khalayak sasaran. Sedangkan posttest dilakukan untuk mengetahui daya serap materi sosialisasi yang sudah diberikan.

Proses analisis data dilakukan dengan menggunakan uji perbandingan ratarata pengetahuan khalayak sasaran antara sebelum dan sesudah.

\section{HASIL DAN PEMBAHASAN}

Kegiatan sosialisasi dilakukan di Kantor DPD Partai Nasdem Kota Serang yang diikuti oleh 109 orang pengurus DPC partai se-Kota Serang. Peserta sangat bersemangat dan sangat antusias mengikuti sosialisasi dan sangat aktif tanya jawab.

Tabel 1. Pemahaman Peserta terhadap pilar kebangsaan yang pertama (Pancasila)

\begin{tabular}{|c|c|c|}
\hline Deskripsi & Sebelum sosialisasi & Sesudah sosialisasi \\
\hline Sangat kurang paham & 14 & 3 \\
\hline
\end{tabular}




\begin{tabular}{|l|c|c|}
\hline Kurang Paham & 65 & 5 \\
\hline Cukup & 27 & 22 \\
\hline paham & 2 & 63 \\
\hline Sangat paham & 1 & 16 \\
\hline Jumlah & 109 & 109 \\
\hline
\end{tabular}

Berdasarkan tabel di atas dapat dipahami bahwa, pemahamanan khalayak sasaran pada pilar pertama (Pancasila) sebelum sosialisasi masih sangat kurang, terbukti masih ada 79 orang yang sangat kurang paham dan kurang paham. Setelah penyuluhan, pemahaman peserta sudah sangat baik. Dari 109 orang, sudah ada 16 orang yang sangat paha, 63 paham, dan 22 cukup paham. Hanya ada 5 orang yang kurang paham dan masih ada 3 orang yang sangat tidak paham. Mereka yang sangat tidak paham tersebut disebabkan mereka ijin saat diberi sosialisasi dan Kembali pada saat post test dilakukan.

Tingkat pemahaman pada aspek Pancasila (Materi 1) dapat Digambarkan dalam bentuk diagram tampak sebagai berikut.

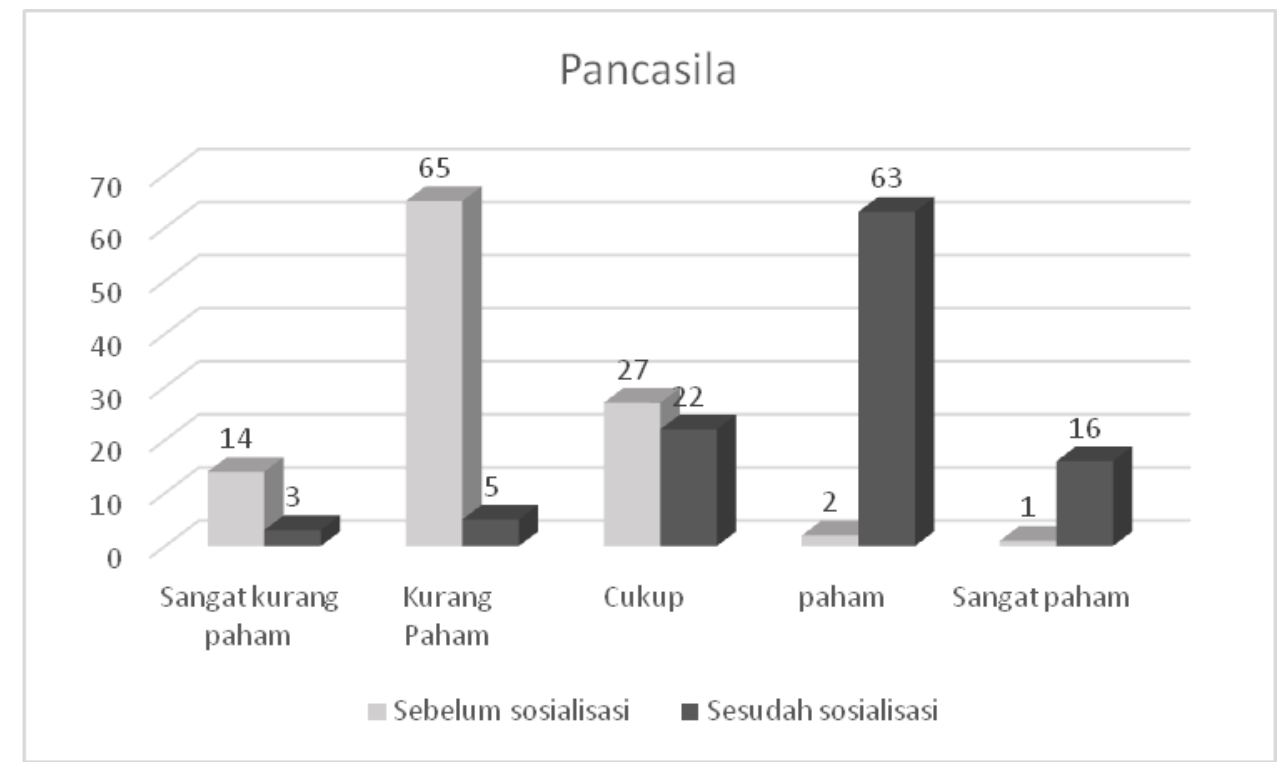

Diagram 1. Pemahaman Peserta terhadap pilar kebangsaan yang pertama (Pancasila)

Pada pilar kedua yaitu Undang-Undang Dasar 1945, hasil pemahaman peserta sosialisasi tampak sebagai berikut.

Tabel 2. Pemahaman Peserta terhadap pilar kebangsaan yang Kedua (UUD 1945)

\begin{tabular}{|l|c|c|}
\hline \multicolumn{1}{|c|}{ Deskripsi } & Sebelum sosialisasi & Sesudah sosialisasi \\
\hline Sangat kurang paham & 17 & 1 \\
\hline Kurang Paham & 63 & 20 \\
\hline Cukup & 28 & 67 \\
\hline paham & 1 & 3 \\
\hline
\end{tabular}




\begin{tabular}{|l|c|c|}
\hline Sangat paham & 1 & 18 \\
\hline Jumlah & 109 & 109 \\
\hline
\end{tabular}

Berdasarkan tabel di atas dapat dipahami bahwa, pemahamanan khalayak sasaran tentang empat pilar kebangsaan pada pilar Kedua (UUD 1945) sebelum sosialisasi masih sangat kurang, terbukti masih ada 80 orang yang sangat kurang paham dan kurang paham. Setelah sosialisasi, pemahaman peserta sudah sangat baik. Dari 109 orang, sudah ada 18 orang yang sangat paha, 67 paham, dan 20 cukup paham. Hanya ada 4 orang yang kurang paham dan masih ada 3 orang yang sangat tidak paham.

Tingkat pemahaman pada Pilar II (Materi UUD 1945) dapat digambarkan dalam bentuk diagram tampak sebagai berikut.

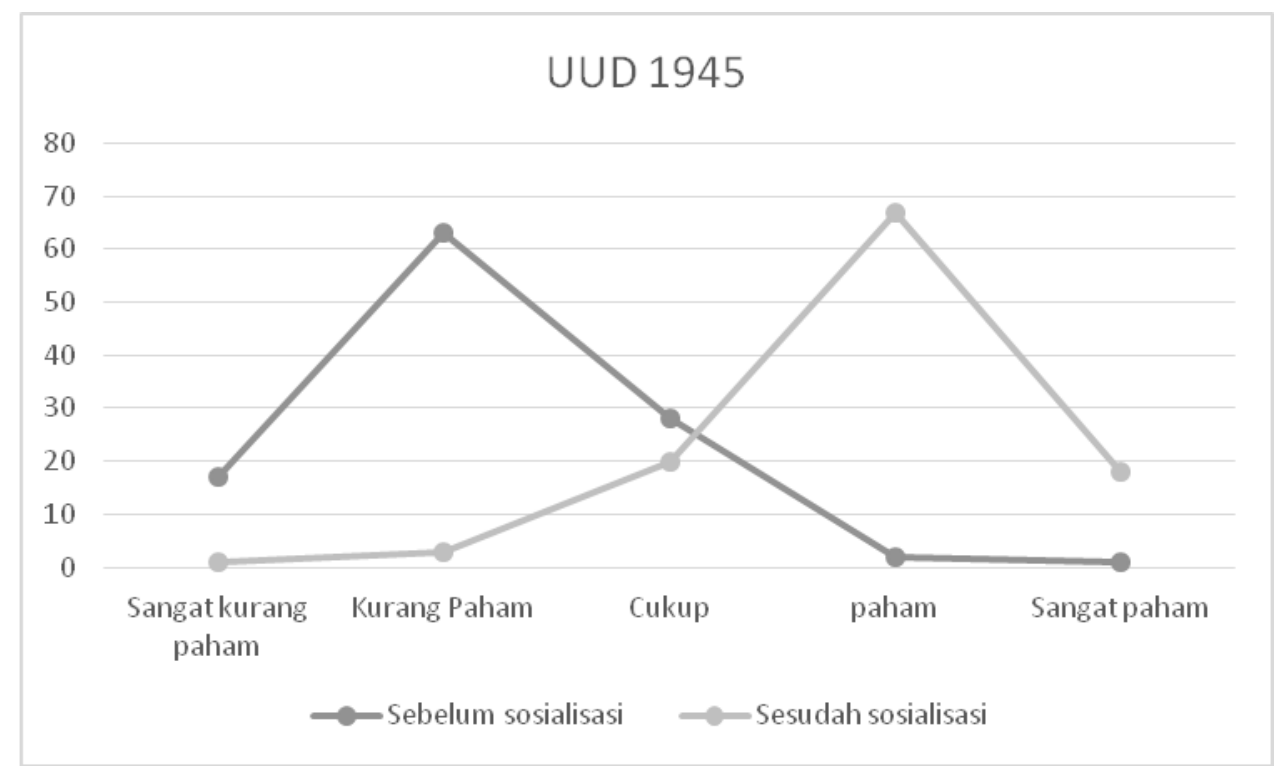

Diagram 2. Pemahaman Pilar Kedua UUD 1945 berikut.

Pada pilar ketiga yaitu NKRI, hasil pemahaman peserta sosialisasi tampak sebagai

Tabel 3. Pemahaman Peserta terhadap pilar kebangsaan yang ketiga (NKRI)

\begin{tabular}{|l|c|c|}
\hline \multicolumn{1}{|c|}{ Deskripsi } & Sebelum sosialisasi & Sesudah sosialisasi \\
\hline Sangat kurang paham & 20 & 0 \\
\hline Kurang Paham & 63 & 2 \\
\hline Cukup & 22 & 22 \\
\hline paham & 3 & 64 \\
\hline Sangat paham & 1 & 21 \\
\hline Jumlah & 109 & 109 \\
\hline
\end{tabular}


Berdasarkan tabel di atas dapat dipahami bahwa, pemahamanan khalayak sasaran tentang empat pilar kebangsaan ketiga (NKRI) sebelum sosialisasi masih sangat kurang, terbukti masih ada 83 orang yang sangat kurang paham dan kurang paham. Setelah sosialisasi, pemahaman peserta sudah sangat baik. Dari 109 orang, sudah ada 21 orang yang sangat paham, 64 paham, dan 22 cukup paham. Hanya ada 2 orang yang kurang paham dan tidak ada seorang pun yang sangat tidak paham.

Tingkat pemahaman pada Pilar III (NKRI) dapat digambarkan dalam bentuk diagram tampak sebagai berikut.

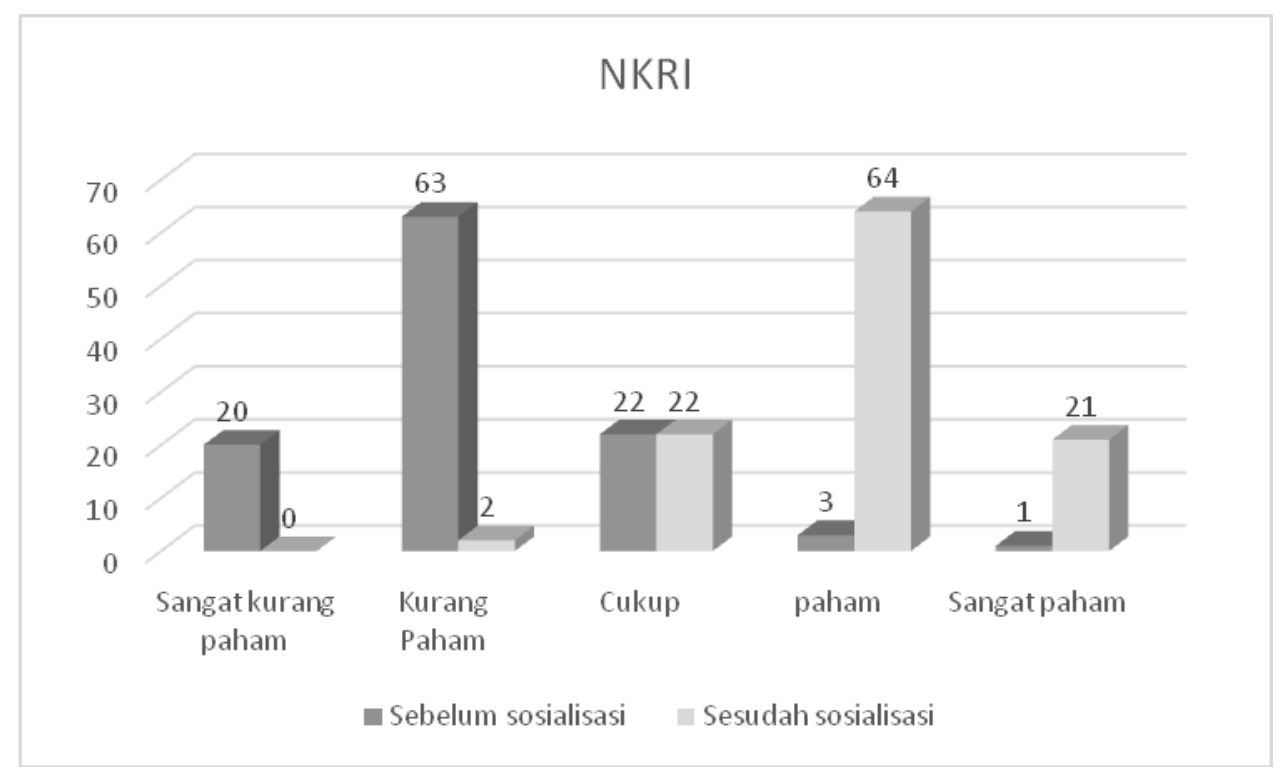

Diagram 3. Pemahaman Pilar ketiga NKRI

Pada pilar keempat yaitu Bhinneka Tunggal Ika, hasil pemahaman peserta sosialisasi tampak sebagai berikut.

Tabel 4. Pemahaman Peserta terhadap pilar kebangsaan yang Kedua (UUD 1945)

\begin{tabular}{|l|c|c|}
\hline \multicolumn{1}{|c|}{ Deskripsi } & Sebelum sosialisasi & Sesudah sosialisasi \\
\hline Sangat kurang paham & 15 & 0 \\
\hline Kurang Paham & 67 & 1 \\
\hline Cukup & 25 & 20 \\
\hline paham & 1 & 70 \\
\hline Sangat paham & 1 & 18 \\
\hline Jumlah & 109 & 109 \\
\hline
\end{tabular}

Berdasarkan tabel di atas dapat dipahami bahwa, pemahamanan khalayak sasaran tentang empat pilar kebangsaan pada pilar keempat (Bhinneka tunggal ika) sebelum sosialisasi masih sangat kurang, terbukti masih ada 82 orang yang sangat kurang paham dan kurang paham. Setelah sosialisasi, pemahaman peserta sudah sangat baik. Dari 109 orang, sudah ada 18 orang yang sangat paham, 70 paham, dan 18 cukup paham. Hanya ada 1 orang yang kurang paham dan tidak ada seorang pun yang sangat tidak paham. 


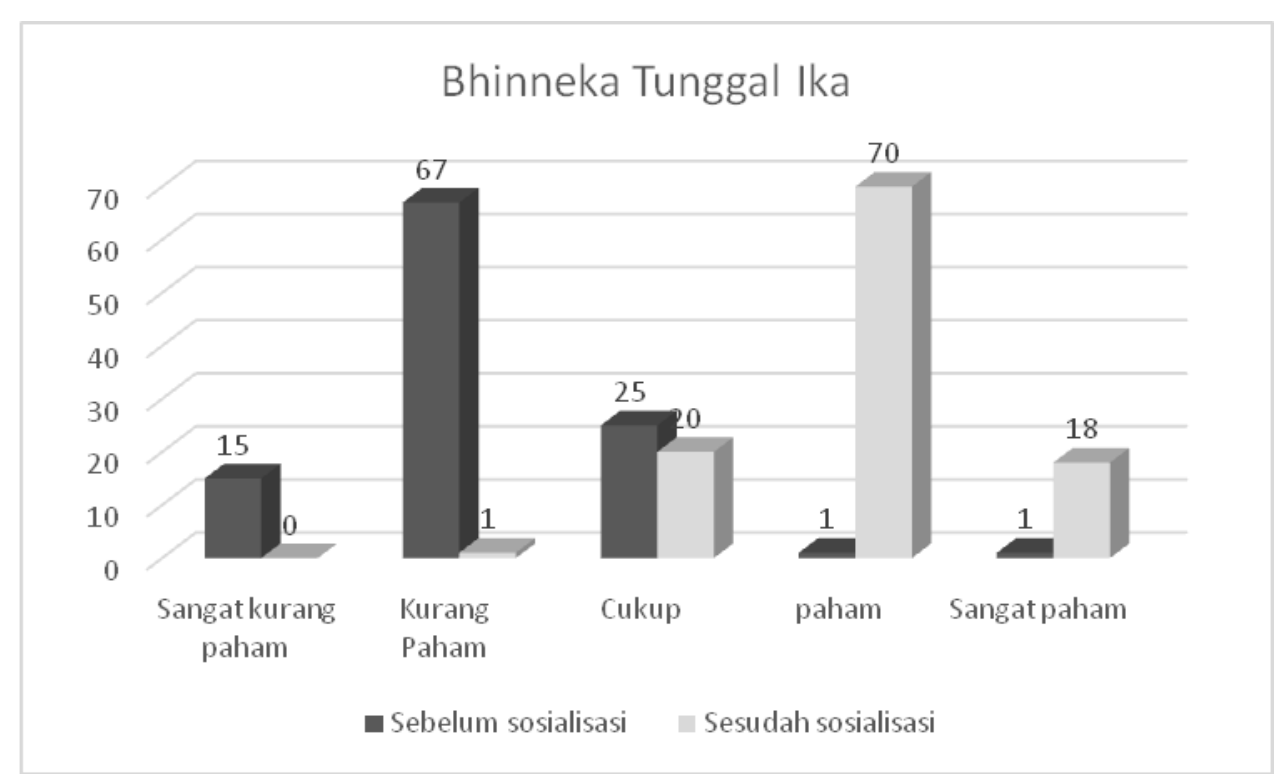

Diagram 4. Pemahaman pilar keempat Bhinneka Tunggal lka.

Kegiatan sosialisasi dapat digambarkan sebagai berikut.

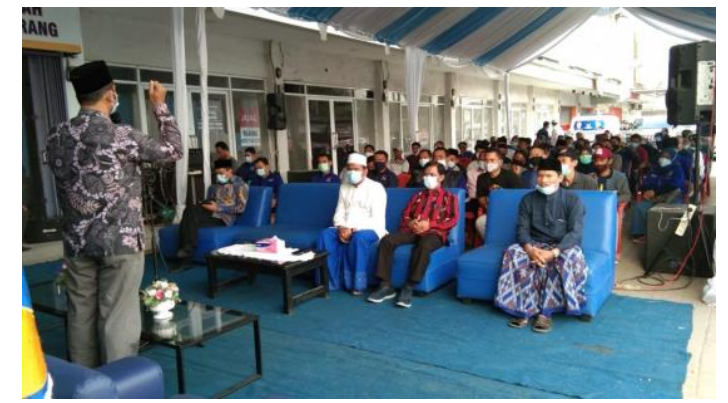

Gambar 1. Pemberian Materi

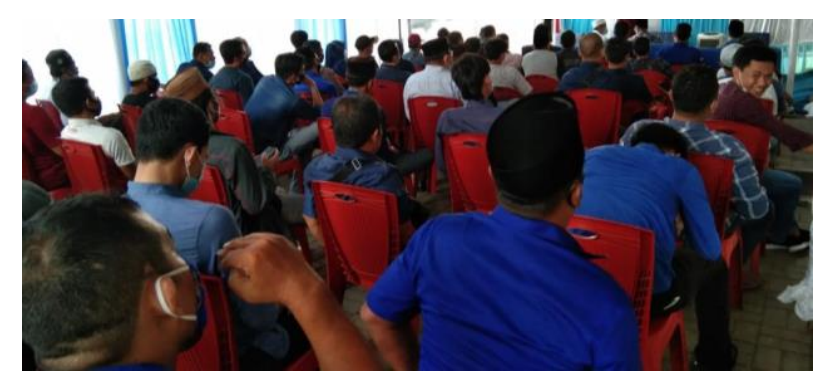

Gambar 2. Para peserta serius Mengikuti Sosialisasi

\section{KESIMPULAN}

Berdasarkah hasil analisis terdapat perubahan pemahaman yang sangat berarti antara sebelum dan sesudah sosialisasi. Para peserta sosialisasi menjadi sangat paham tentang empat pilar kebangsaan mulai dari Pancasila, UUD 1945, NKRI, dan Bhinneka Tunggal lka. 
Peningkatan yang terjadi sebesar $35 \%$ dari rata-rata nilai $42 \%$ menjadi rata-rata $77 \%$. Melalui kegiatan pengabdian ini, dapat dilakukan tindak lanjut, sehingga empat pilar kebangsaan tersebut dapat terlaksana dengan baik

Dengan kata lain, mayoritas peserta sosialisasi menjadi lebih paham bagaimana mengamalkan Pancasila, UUD 1945, mewujudkan NKRI dan menghormati adanya Bhineka Tunggal lka. Ke depan kegiatan seperti ini dapat terus dilanjutkan pada lingkup yang lebih luas sehingga seluruh masyarakat Indonesia dapat meningkat pemahamannya di bidang empat pilar kebangsaan.

\section{UCAPAN TERIMA KASIH}

Penulis mengucapkan terima kasih kepada DPRD Provinsi Banten yang telah memberi dukungan financial terhadap pengabdian ini.

\section{DAFTAR PUSTAKA}

BPIP (2020) Empat Pilar Kebangsaan Indonesia. http://www.bpip.go.id

Kemenkumham. (2020) Empat Pilar Kebangsaan sebagai Aktor Pendukung Menuju Masyarakat yang sadar Hukum. https://jatim.kemenkumham.go.id/pusatinformasi/artikel/2322-empat-pilar-kebangsaan-faktor-pendukung-menuju-masyarakatyang-sadar-hukum

Kemeninfokom. 2020. Tingkatkan Komitmen Berbangsa dan Bernegara Melalui Empat Pilar Kebangsaan. https://www.kominfo.go.id/content/detail/24590/tingkatkan-komitmenberbangsa-dan-bernegara-melalui-empat-pilar-kebangsaan/0/berita

\section{Jurnal:}

Bhuvaneswari, K., Geethalakshmi, V., Lakshmanan, A., Srinivasan, R., \& Sekhar, N. U. (2013). The impact of El Nino/ Southern Oscillation on hydrology and rice productivity in the Cauvery Basin, India: Application of the soil and water assessment tool. Weather and Climate Extremes, 2, 39-47.

Brennan, M. A., \& Israel, G. D. (2008). The power of community. Community Development, 39(1), 82-97.

Suseno, Bambang Dwi; Yusuf, Furtasan Ali; Pawirosumarto, Suharno.(2020). The Citizenship Engagement Quality in ASEAN and the Sustainability of ASEAN Economic Community Performance, International Journal of Psychosocial Rehabilitation, Vol. 24, No.2. pp. 2808-2820.

Saefudin, S; Suseno, BD, Nuryanto, UW. (2019). Peran Kontrak Psikologis Sebagai Pengungkit Kinerja Pelabuhan Perikanan Nusantara Karangantu Banten, Tirtayasa Ekonomika, Vo. 14, issue 2, pp. 232-246

\section{Buku:}

McKibbin, B. (2007). Deep economy: The wealth of communities and the durable future. New York: Times Books/Henry Hold and Co.

\section{Chapter in an edited book:}

Pigg, K. E., \& Bradshaw, T. K., (2003). Catalytic community development: A theory of practice for changing rural society. In D. L. Brown \& L. E. Swanson (Eds.), Challenges 
for rural America in the twenty-first century (pp. 385-396). University Park, PA: Pennsylvania State University Press.

\section{Sumber Internet}

U.S. Census Bureau. (2000). State and Country QuickFacts. Washington, D.C.: United States Bureau of the Census. Retrieved November 7, 2008, from http://quickfacts.census.gov/gfd/ 